\title{
The Impact of Sino-US Trade War on Chinese Industrial Structure and Countermeasure
}

\author{
Man Sheng \\ Shanghai University, China \\ smh1993123@sina.cn
}

Keywords: US-China trade war; Industrial structure; Import and export country model

\begin{abstract}
In recent years, the world economy tends to improve. The negative impact of the financial crisis on the economy is decreasing. However, it seems that most countries do not have enough confidence in sustained economic growth. The process of globalization is blocked, and the challenges of trade protectionism are increasing. Under the background, US-China Trade War broke out. The scale of this trade war is incomparable. The "war" will have a profound impact on the economy of our country and the whole world. Based on the analysis of the present situation of Sino-US trade, this paper tries to study the influence mechanism of the US-China trade war on industrial structure, and put forward some countermeasures and suggestions.
\end{abstract}

\section{Preface}

On June 15, 2018, The United States issued a statement saying it would impose a $25 \%$ punitive tariff on about $\$ 50$ billion of Chinese exports. On July 6 , the first round of U.S. punitive tariffs on Chinese goods came into effect, and the Sino-US trade war officially unveiled. It is by far the largest trade war, and it will have profound implications on the Chinese economy in recent years.

Since the 1990s, in order to promote development, our government has adopted export-oriented policies. Coupled with the demographic dividend, China has comparative advantages in labor-intensive products, which makes a large number of Chinese products into the United States market. Although the United States has comparative advantages in high-tech products, its trade deficit with China is growing because of its strict export control of high-tech products. The huge deficit has become one of the reasons for the frequent trade friction between China and the United States in recent years[1].

With the transformation and upgrading of Chinese economic structure, products between China and the United States have gradually changed from complementary to competitive. This shift has led the United States to consider China as a major competitor. From the list of Chinese goods to be taxed, we can see that the top ten high-tech industries of "Made in China 2025" are the targets of this trade war. On the one hand, the measure reflects the change of US trade policy. On the other hand, it reflects the urgency of Chinese industrial restructuring. It is necessary to assess and forecast the impact of trade frictions on China's economy and take further countermeasures in the face of the escalating trade frictions.

This paper will analyze the current situation of Sino-US trade and the impact mechanism of this trade war on Chinese industrial restructuring, and put forward possible countermeasures.

\section{Analysis on the Development of Sino-US Bilateral Trade}

General Situation of Sino-US Bilateral Trade. Since the establishment of Sino-US trade relations, bilateral trade exchanges have become increasingly frequent, and bilateral trade volume has also achieved rapid growth. According to statistics from the Ministry of Commerce, Sino-US trade volume increased from US \$245 thousand in 1979 to US \$33 million 378 thousand in 2008. Especially since China joined the World Trade Organization in 2001, the volume of trade between China and the United States has increased by $20 \%$ annually. According to the National Reporting Network of the Ministry of Commerce, the total bilateral trade between China and the United States in 2007 was 384.4 billion US dollars, which increased to 636 billion US dollars in 2017, increased 
by $65.46 \%$ (as shown in Figure 1, source from China Ministry of Commerce National Report Network). By 2017, the United States had become Chinese second largest trading partner (after the European Union), while China was American first largest trading partner.

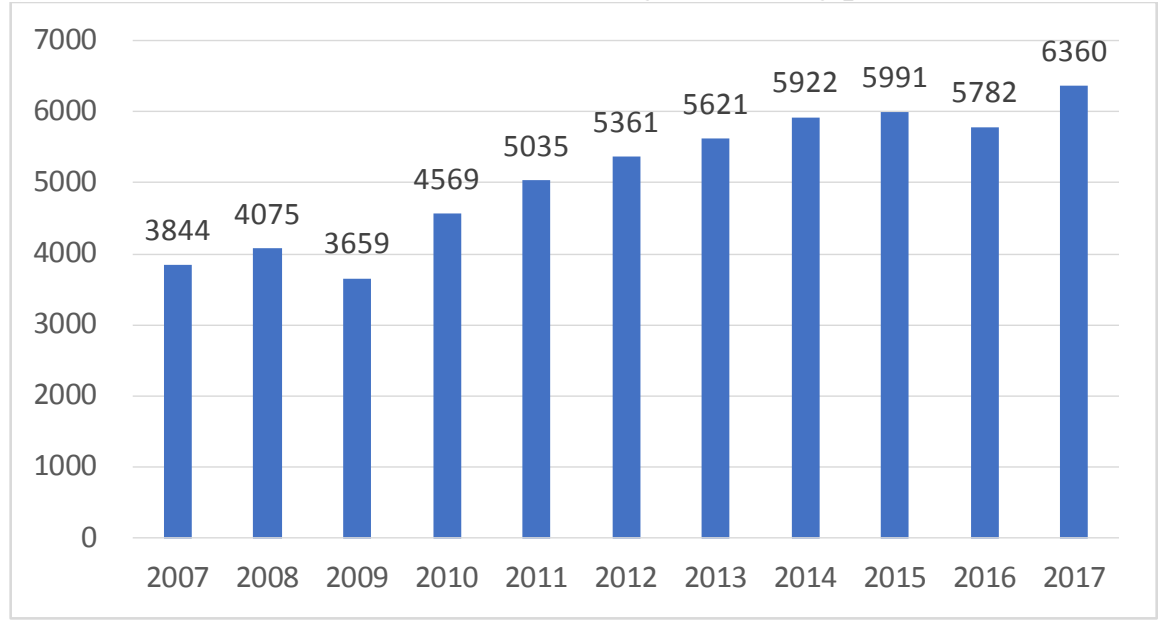

Figure 1. 2007-2017 Annual Sino-US bilateral trade volume (unit: Billion USD)

While Sino-US trade contacts have become increasingly close, the continuous expansion of the US trade deficit with China has become a hindrance to the further development of bilateral trade. In 2017, US exports to China amounted to US \$13.37 billion; US imports from China amounted to US $\$ 50.56$ billion. The US trade deficit was 375 billion 230 million US dollars, increased by $8.1 \%$ (as shown in Figure 2, source from China Ministry of Commerce National Report Network). Despite the slowdown in trade deficit growth in recent years and even negative growth in 2016, the overall U.S. trade deficit with China is still expanding. This has also become a direct fuse for trade disputes between China and the United States.

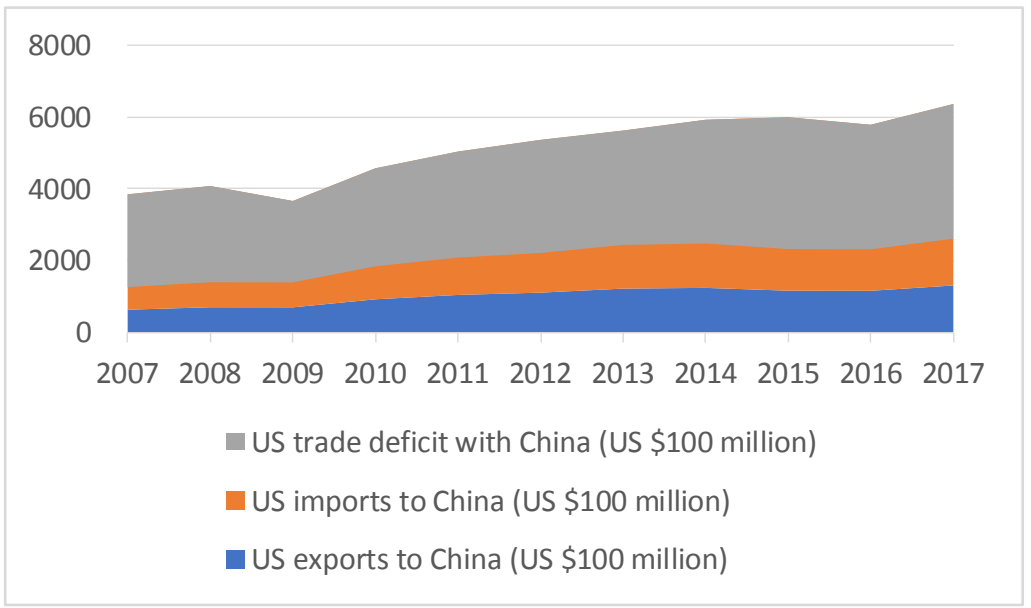

Figure 2. Sino-US import and export volume and US trade deficit with China

On the whole, the trade between China and the United States is very close. In terms of exports, the two sides are increasingly dependent on each other. In comparison, the U.S. dependence on Chinese exports is much lower than Chinese dependence on U.S. exports. In terms of imports, China and the United States have decreased their dependence on each other. At the same time, China's trade surplus with the United States as a whole is expanding. In this case, the impact of the United States to take countermeasures on China's economy is enormous.

Sino-US Trade Friction. The trade frictions between China and the United States have been continuing. After Chinese accession to the World Trade Organization, although the number of U.S. anti-dumping cases against China has decreased year by year, the frequency of filing cases is still the highest. In the early years, light industry, textiles and chemical products were the main areas of trade disputes between China and the United States. With the optimization and upgrading of 
Chinese industrial structure, high value-added products affected by trade friction tended to increase [2].

In fact, if we strictly follow the comparative advantage theory and product life cycle theory, China exports labor-intensive products to the United States, the United States exports technology-intensive products to China, and the total import and export volume of China and the United States will generally balance [3]. However, because the United States imposes import restrictions on China in the high-tech industries which occupy a comparative advantage, this high value-added industry cannot play its role in balancing trade balance and gradually enlarges the trade deficit. With the adjustment of Chinese industrial structure and the export restrictions of the United States, this trade imbalance will exist for a long time, so Sino-US trade friction will also become a long-term phenomenon. Under the circumstances that the Sino-US trade war is irreversible in the short term and may continue to escalate, how to reduce the negative impact of the trade war and steadily promote Chinese economic transformation and upgrading is the priority in the current economy and trade field.

\section{Analysis on the Influence Mechanism of Sino-US Trade War}

The main measure taken by the United States in this trade war is to impose punitive tariffs, which is a price restriction and will increase the prices of related products in the United States.

This part will analyze the impact of Sino-US trade war on Chinese industrial structure through Hamilton and Reed's Import and Export Country Model, which uses a importing countriy and two exporting countries to simply simulate international trade[4]. The model has three assumptions. First, the markets of each country are completely competitive. Second, there are only three countries in the world -the importing country (the United States, denoted as A), the sanctioned country (China, denoted as C), the free trade country (denoted as F). Third, the productivity of the free trade country is lower than that of China. Fourth, there is no trade friction between China and USA, and China and the free trade country do not trade each other.

Positive Effect. As shown in Figure 5, the supply curves of China and the United States are $\mathrm{S}_{\mathrm{A}}$ and $\mathrm{S}_{C}$ respectively. The demand curves are $\mathrm{D}_{\mathrm{A}}$ and $\mathrm{D}_{\mathrm{C}}$. The import demand curves of the United States to the free trade countries are $\mathrm{ID}_{\mathrm{A}}$. The export supply curves of the free trade countries are $\mathrm{ES}_{\mathrm{F}}$. The import demand curves of the United States to China are $\mathrm{ID}_{\mathrm{A}-\mathrm{F}}$ and the export supply curves of China are $\mathrm{ES}_{\mathrm{C}}$. In the case of Sino-US free trade, the commodity price is $\mathrm{P}_{0}$, and the supply gap of the United States, that is, the import volume of the United States, is $\mathrm{A}_{0} \mathrm{~A}_{\mathrm{O}}$ '. The export of the free trade countries to the United States is $\mathrm{OF}_{0}$, and the export of China to the United States is $\mathrm{OC}_{0}$.

When the United States imposed punitive tariffs on Chinese goods, the price of domestic goods rose to $\mathrm{P}_{1}$, while the demand for imports fell to $\mathrm{A}_{1} \mathrm{~A}_{1}{ }^{\prime}$, the imports of the United States to China fell from $\mathrm{OC}_{0}$ to $\mathrm{OC}_{1}$, and the imports to the third-party free trade country rose to $\mathrm{OF}_{1}$.

From Chinese perspective, due to the decrease in US demand, Chinese exports have fallen. To expand domestic demand, the price of this commodity in China has fallen to P2. As far as welfare is concerned, producer surplus has decreased in China, the decrease is $n+q$ in the graph. As a result of the decrease in price, consumer surplus has increased, and the increase is $n$ in the graph. The net surplus reduction is $(\mathrm{n}+\mathrm{q})-\mathrm{n}=\mathrm{q}$, that is, $\mathrm{k}+\mathrm{m}$. At the same time, tariffs imposed by the United States will lead to an increase in commodity rents of $\mathrm{G}+\mathrm{k}$. The $\mathrm{k}$ comes from Chinese exporters affected by the punished tariffs, and $G$ from the United States, where the total benefits are $(\mathrm{g}+\mathrm{k})-(\mathrm{k}+\mathrm{m})=$ G-M. 


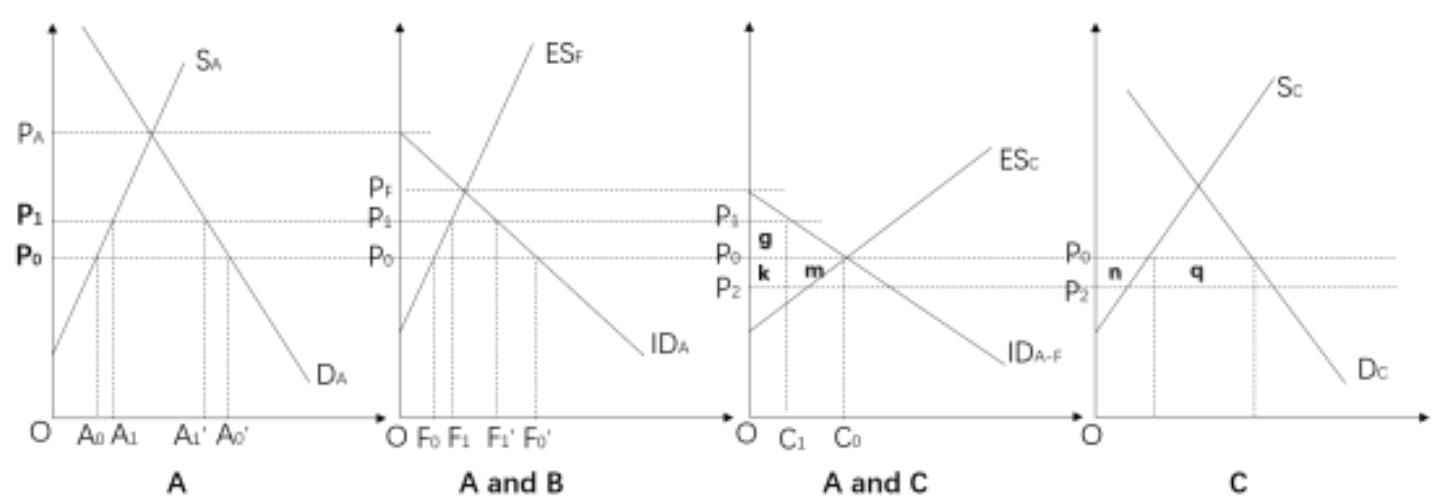

Figure 3. Import and Export Country Model

Therefore, under other conditions unchanged, the impact of tariff on Chinese social welfare depends on the strength of tariff. If the rent brought by the trade war is greater than the reduction of the net surplus of the producers, then the total welfare will increase. Taking corresponding measures from this angle, it will reduce the impact of the trade war on our industry, and profit simultaneously.

Negative Effect. Since the goods subject to tariff increases are specific, rent $\mathrm{K}$ will shift from industries affected by the trade war to industries unaffected or less affected by tariff increases. From the list of tax increases in the trade war, we can consider that this trade war covers the ten strategic industries of Made in China 2025. If we only rely on the free adjustment of the market, it will lead to the loss of capital in this part of the industry, thus affecting the optimization and upgrading of industrial structure.

\section{Countermeasures}

From the analysis above, we can see that the impact of Sino-US trade war on Chinese economy should not be underestimated. In order to reduce the negative impact and realize the goal of optimizing and upgrading Chinese industrial structure, we need to adopt the measures and work together at home and abroad.

Firstly, Whether exporting or importing, relying too much on a country is a risky behavior. China should give full play to its geopolitical advantages, continue to promote the Belt and Road, strengthen the construction of free trade zones with neighboring countries, and develop multilateral trade relations. At the same time, we should seek trade cooperation opportunities with various trading partners to reduce dependence on US exports and reduce the impact of trade frictions on our economy.

Secondly, In some key areas, such as chips and information systems, we must actively learn from foreign technological experience, enhance the ability of independent innovation, intensify research and development, and reduce external dependence. Only in this way can we truly grasp the lifeblood of economic development and the voice of international negotiations.

Lastly, Sino-US trade war has a great negative impact on the development of Chinese high-tech industries. It is not enough to rely solely on the adjustment of market forces. The government must support strategic industries from the policy level, reduce the containment of trade war on these industries, so as to optimize and upgrade the industrial structure.

\section{Reference}

[1] Lv Chuncheng, Principles of International Trade, China Finance and Economics Press, 2002.

[2] Prusa, Thomas J., and S. Skeath, The economic and strategic motives for antidumping filings, Weltwirtschaftliches Archiv 138.3(2002):389-413.

[3] Goromi, Global Trade and National Interest Conflict, CITIC press, 2003.

[4] Yao Fang, China's industrial structure adjustment under the background of Sino US interest friction, Xiamen University. 2009. 
[5] Fogli A, Perri F. The "Great Moderation" and the US External Imbalance, Working Papers. 2006

[6] Lv R S, Wang C H. A Comparative Study between Sino-US and Japan-US Trade Frictions with Big Data Technology, Applied Mechanics \& Materials. 2014.

[7] Lewrick U, Schanz J, Liquidity Risk in Markets with Trading Frictions: What Can Swing Pricing Achieve, Bis Working Papers. 2017.

[8] Bian J Y, Department F L, The Study of China's Foreign Trade Friction, Characteristics, Causes and Countermeasures, Prices Monthly. 2014.

[9] Zhang Zhongshou, Wang Shiwen, Economic Motivation and Countermeasure of Trade Friction, Macroeconomic Research. 2011 (11): 47-51.

[10] Tao Haidong, Characteristics and Countermeasures of Sino-US Trade Frictions, Business Economics Research. 2017 (4): 141-142. 